\title{
PENGARUH INFUSA TEH HITAM (CAMELIA SINENSIS) TERHADAP GAMBARAN HISTOPATOLOGI HEPAR, RENAL DAN JUMLAH SEL-SEL ALFA DAN BETA PANKREAS TIKUS JANTAN SPRAGUEDAWLEY DIINDUKSI ETANOL 20\%
}

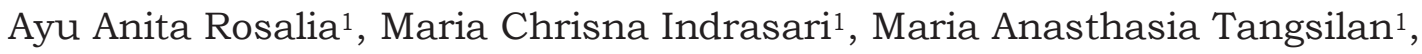
Tejo Jayadi ${ }^{2}$, Sulanto Saleh Danu ${ }^{3}$

${ }^{1}$ Fakultas Kedokteran, Universitas Kristen Duta Wacana

${ }^{2}$ Bagian Patologi Anatomi, Fakultas Kedokteran Universitas Kristen Duta Wacana 3Bagian Farmakologi Klinik, Fakultas Kedokteran Universitas Gadjah Mada

Korespondensi: tejo_jayadi@staff.ukdw.ac.id

\begin{abstract}
ABSTRAK
Latar Belakang: Fungsi antioksidan dari teh telah banyak diteliti. Teh hitam memiliki kandungan utama theaflavins, thearubigins dan catechins. Konsumsi etanol kronik dalam jumlah besar dapat menyebabkan gangguan fungsi hepar, pankreas dan ren, yang disebabkan terutama disebabkan oleh proses stres oksidatif. Tujuan penelitian ini adalah untuk mengkaji pengaruh infusa teh hitam terhadap gangguan beberapa organ tersebut diinduksi etanol diteliti.

Metode: Penelitian ini merupakan penelitian eksperimental murni dikerjakan dengan rancangan completely randomized design, dengan 6 kelompok eksperimental yang masing-masing menggunakan 5 ekor tikus. K1 kontrol normal; K2 diberi infusa teh hitam 0,252 gr/ 200 grBB; (K3) diberi etanol 20\% dengan volume $2 \mathrm{ml}$ / hari; $\mathrm{K} 4, \mathrm{~K} 5$ dan $\mathrm{K} 6$ yaitu kelompok perlakuan diberi etanol $20 \%$ volume $2 \mathrm{ml}, 1$ jam kemudian diberi infusa teh hitam dengan dosis $0,126 \mathrm{gr} /$ 200 grBB; 0,252 gr/ 200 grBB;0, 50 gr/ 200 grBB setiap hari. Pada hari ke 31 hewan coba diterminasi dan diambil jaringan hepar, pankreas, dan renal. Kemudian dilakukan pembuatan sediaan histopatologi pada organ hepar dan ginjal, sediaan dengan pewarnaan histokimia Victoria blue.

Hasil: Pengamatan dan analisis sediaan histopatologi hepar menunjukkan adanya perbedaan bermakna $\mathrm{p}=0,004(\mathrm{p}<0,05)$; sediaan pankreas menunjukkan adanya perbedaan bermakna jumlah rata-rata sel alfa dan sel beta pulau Langerhans pankreas, yaitu $\mathrm{p}=0,002$ untuk sel alfa dan 0,00 untuk sel beta $(\mathrm{p}<0,05)$; sediaan renal menunjukkan adanya perbedaan bermakna rata skor kerusakan ginjal $\mathrm{p}=0,001(\mathrm{p}<0,05)$.

Kesimpulan: Infusa teh hitam memperbaiki gambaran histopatologi hepar dan ren, serta meningkatkan jumlah sel-sel alfa dan sel-sel beta pankreas pada tikus putih (Sprague Dawley) yang diberi etanol 20\% kronik.
\end{abstract}

Kata Kunci: teh hitam, alkohol, hepar, pankreas, renal. 


\title{
THE EFFECT OF BLACK TEA INFUSION (CAMELIA SINENSIS) TO HISTOPATHOLOGICAL PICTURES OF LIVER, KIDNEY AND THE AMOUNT OF ALPHA AND BETA CELLS OF PANCREAS OF SPARGUE DAWLEY MALE RATS INDUCED BY ETHANOL 20\%
}

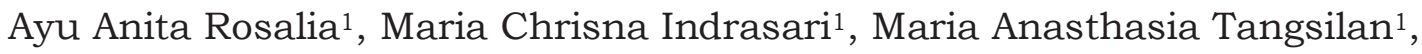
Tejo Jayadi2, Sulanto Saleh Danu ${ }^{3}$

${ }^{1}$ Medical Faculty of Duta Wacana Christian University

2Anatomical Pathology Division, Medical Faculty of Duta Wacana Christian University

${ }^{3}$ Clinical Pharmacology Division, Medical Faculty of Gadjah Mada University

Correspondence: tejo_jayadi@staff.ukdw.ac.id

\begin{abstract}
Backgroud and Aim: Many research of tea antioxidant function have been establish. Major contains of black tea are thearuflavins, therubigins and catechins. Chronis consumption of ethanol could caused hepar, pancreas and renal disturbance. The effect of black tea infusion toward ethanol organs disturbance will be researched.

Methods: The research was carried out with the method of true experimental with post-test only control group design, with six groups and five rats on each group. $K 1$ normal control; K2 were given black tea infusion 0,252 gr/ $200 \mathrm{grBB} ; \mathrm{K} 3$ were given $2 \mathrm{ml}$ ethanol 20\%; K4, K5 and K6 treatment group were given ethanol 20\%, one our later each of rat were given black tea infusion with doses $0,126 \mathrm{gr} / 200 \mathrm{grBB}$; $0,252 \mathrm{gr} / 200 \mathrm{grBB}$ and $0,5 \mathrm{gr} / 200 \mathrm{grBB}$ every day. On day $31^{\text {th }}$ all rats were terminated. Liver, pancreas and renal were collected, and then it were made histophatological preparation on liver and renal, and Victoria blue stainning on pncreas.

Results: Analysis and observation of liver histopatology preparation were showed the significant difference $p=0,004(p<0,05)$; pancreas Victoria blue stainning were showed significant difference of the amount of alpha cells $p=0,002$ and beta cells 0,000 of pancreatic langerhans islets $(p<0,05)$; renal histopathology preparation were showed significant difference $p=0,001(p<0,05)$.

Conclusion: Black tea infusion ameliorate histopathological pictures of hepar, renal and increase the amount of alpha cell and beta cell of pancreatic langerhans islets in white rat (Sprague Dawley) induced by ethanol 20\%.
\end{abstract}

Keywords: black tea, ethanol, liver, pancreas, renal. 


\section{PENDAHULUAN}

Teh adalah minuman yang terpopuler, murah dan dikonsumsi oleh banyak orang. Ada tiga jenis the, yaitu teh hijau yang tidak terfermentasi; teh oolong yang terfermentasi sebagian; dan teh hitam yang terfermentasi sempurna. Fermentasi pada pemrosesan ini adalah perubahan oksidatif dan enzimatik di dalam daun the. ${ }^{1}$ Jenis teh yang banyak dikonsumsi adalah teh hitam, kemudian teh hijau. Enam kelompok bioflavanoid yang terkandung dalam daun teh memiliki aktivitas antioksidan yang beberapa puluh kali lebih kuat dibandingkan $a$ tocopherol, vitamin $\mathrm{C}$, dan $\beta$-carotene. Antioksidan utama dalam teh adalah catechins, theflavins, thearubigins, oxyaromatic acids, flavonols, flavones, dan derivat gallic acid.2,3 Flavanoid terbanyak dalam daun teh adalah flavanols ${ }^{4}$, catechins adalah flavanols terbanyak dalam daun the. ${ }^{2}$ Selama proses fermentasi daun teh hijau, sebagian catechins teroksidasi atau terkondensasi menjadi molekul polifenol lebih besar, theaflavins dengan kadar 3-6\%, therubigins dengan kadar $12-18 \%$ dan catechins dengan kadar 3-10\% dalam teh hitam. Polimer ini memberi rasa pahit dan warna hitam pada the. 5,6 Kandungan flavanols adalah sekitar $17 \mathrm{~g}$ per $100 \mathrm{~g}$ teh hitam kering, terdiri dari catechins adalah monomer dengan komposisi sebesar 3-10\%; theaflavins adalah dimer dari derivat tanin dengan komposisi 2-6\%; thearubigins adalah oligomer dari derivat tanin dengan komposisi $10-20 \% .4,7$ Teh hijau mengandung 4 kali antioksidan catechins dibandingkan teh hitam, sekitar $70 \mathrm{mg}$ catechins per $100 \mathrm{~mL}$ dibandingkan $15 \mathrm{mg}$ per $100 \mathrm{~mL}$ teh hitam. ${ }^{1}$

Rata-rata aktivitas antioksidan catechins dalam teh hijau jauh lebih besar dibandingkan teh hitam yakni $92,1 \%$ dibandingkan $28,8 \%$, theaflavins hanya terdapat dalam teh hitam memiliki aktivitas antioksidan $27 \%$, sedangkan aktivitas antioksidan thearubigins tidak diteliti. ${ }^{3}$ Pada penelitian in vivo, aktivitas antioksidan dari daun teh, menunjukkan hasil yang beragam, sesuai metode penelitian dan design penelitian yang dipakai. ${ }^{8}$

Status redox seluler, dapat berubah tergantung pada berbagai kondisi patologis, dan dapat disebabkan oleh diet. Salah satunya adalah alkohol, yang dapat menurunkan kemampuan antioksidatif seluler, pembentukan radikal bebas. Intoksikasi alkohol kronik meningkatkan pembentukan spesies oksigen reaktif, terutama radikal superoksida dan peroksida hidrogen. Peningkatan pembentukan radikal superoksida disebabkan karena meningkatnya NADH dan produknya asetaldehid selama metabolisme etanol. Penurunan rasio konsentrasi NAD/NADH mengakibatkan meningkatnya pelepasan ion besi dari ferritin. Peningkatan ion besi bebas, mengkatalisis reaksi radikal bebas menambah peningkatan level radikal bebas pada intoksikasi etanol. Intoksikasi alkohol kronik disertai penurunan aktivitas enzim pemetabolisme etanol, alcohol dan aldehyde dehidrogenase, mengakibatkan penumpukan asetaldehida. Pada kondisi ini xanthine oxidase, mengkatalisis pembentukan radikal superoksida menggunakan acetaldehyde sebagai bahan bakunya. Menurunnya status antioksidan selama intoksikasi alkohol menunjukkan kondisi stres oksidatif. 9 Stres oksidatif akan mengakibatkan peroksidasi lipid sehingga integrasi membran terganggu. ${ }^{10}$ Jalur oksidatif metabolisme alkohol mensensitisasi mitokondria pankreas mengaktifkan mitochondrial permeability transition pore (MPTP), mengakibatkan kegagalan mitokondria; hal ini menyebabkan pankreas lebih rentan 
mengalami nekrosis. ${ }^{11}$ Paparan alkohol kronik dapat mengakibatkan gangguan elektrolit dan kesetimbangan asam basa, hal ini disebabkan disfungsi dari sel epitel tubuler ginjal. ${ }^{12}$

Pola konsumsi alkohol di Indonesia bervariasi antar budaya dan daerah. Beberapa populasi di Indonesia tidak meminum alkohol, dan meminim alkohol dianggap secara sosial tidak dapat diterima. ${ }^{13}$ Prevalensi penduduk laki-laki secara nasional rendah, namun ada klaster spasial di luar Jawa dengan perbedaan prevalensi minum alkohol yang secara bermakna dari angka nasional 4,5\% di perkotaan dan 5,2\% di pedesaan, yaitu di provinsi Sulawasi Utara $31,5 \%$ dan $32,9 \%$, Nusa Tenggara Timur $21,2 \%$ dan $32,5 \%$, dan Gorontalo $19,6 \%$ dan $27,6 \% .14$

Berdasarkan patomekanismenya alkohol telah diketahui efek samping konsumsi alkohol, maka bahanbahan alami yang memiliki aktivitas antioksidan poten perlu diteliti. Daun teh adalah tanaman yang paling banyak mengandung flavanoids, memiliki aktivitas antioksidan kuat. Aktivitas antioksidan teh hitam dapat memberikan perbaikan pada metabolisme etanol sehingga dapat memproteksi hepar dari stres oksidatif akibat intoksikasi alkohol. ${ }^{9}$ Penelitian ini bertujuan untuk mengetahui pengaruh infusa the hitam pada perubahan gambaran histopatologi hepar, pankreas dan renal tikus putih (Sprague Dawley) yang diberi etanol 20\% kronis.

\section{METODE PENELITIAN}

Penelitian ini adalah penelitian eksperimental murni yang dikerjakan di laboratorium secara in vivo dengan rancangan penelitian completely randomized design. Sampel penelitian adalah 30 ekor tikus putih (Sprague Dawley) jantan berumur 2 bulan dengan berat badan 200 gram, diperoleh dari LPPT (Laboratorium Penelitian dan Pengujian Terpadu) Unit IV UGM. Hewan coba tersebut dibagi menjadi 6 kelompok, masingmasing terdiri dari 5 tikus, yaitu: kelompok kontrol negatif (K1) yaitu kelompok hewan coba dengan diet normal tanpa diberi etanol 20\% dan infusa teh hitam; kelompok kontrol sham (K2) yaitu kelompok dengan diet normal diberi infusa teh hitam 0,252 gr/ 200 grBB selama 30 hari dengan sonde oral; kelompok kontrol positif (K3) yaitu kelompok dengan diet normal diberi etanol $20 \%$ dengan volume $2 \mathrm{ml} /$ hari selama 30 hari; kelompok perlakuan 1 (K4) yaitu kelompok dengan diet normal diberi etanol $20 \%$ volume $2 \mathrm{ml}, 1$ jam kemudian diberi infusa teh hitam dengan dosis 0,126 gr/ 200 grBB setiap hari selama 30 hari dengan sonde oral; kelompok perlakuan 2 (K5) yaitu hewan coba dengan diet normal diberi etanol $20 \%$ volume $2 \mathrm{ml}, 1$ jam kemudian diberi infusa teh hitam dengan dosis 0,252 gr/ $200 \mathrm{grBB}$, setiap hari selama 30 hari dengan sonde oral; kelompok perlakuan 3 (K6) yaitu hewan coba dengan diet normal diberi etanol 20\% volume $2 \mathrm{ml}, 1$ jam kemudian diberi infusa teh hitam dengan dosis $0,50 \mathrm{gr} / 200 \mathrm{grBB}$ setiap hari selama 30 hari dengan sonde oral. Pada hari ke 31 hewan coba diterminasi dengan cara dibius secara umum dengan eter dan diambil jaringan hepar, pankreas, dan renal. Kemudian dilakukan pembuatan sediaan histopatologi pada organ hepar dan ginjal, sediaan dengan pewarnaan histokimia Victoria blue.

Struktur mikroskopik dari liver, persentasi lobulus hepatik dengan stetosis dan intensitas steatosis dievaluasi, setiap lobulus dibagi menjadi dua sentral dan perifer. Derajat degenerasi lemak dinilai menggunakan skor semikuantitatif: 0 : normal; $1+$ : ringan $1-25 \%$; $2+$ : 26$50 \%$; 3+: 51-75\%; 4+: 76-100\%.15 
Sediaan pankreas diamati dengan menghitung jumlah sel alfa dan sel beta pankreas pada empat pulau langerhans dan dilakukan penghitungan rata-rata untuk masing-masing kelompok. Pengamatan pada sediaan ginjal dengan membagi preparat dalam empat bagian, pada setiap bagian dilihat luasnya kerusakan sel berupa nekrosis pada glomerulus, tubulus proksimal, tubulus distal. Persentase luas kerusakan ginjal dari ke-4 bagian tersebut kemudian dijumlahkan dan dibagai empat. Kemudian tingkat kerusakan ginjal dinilai sebagai berikut: skror 1 (normal): bila tidak ditemukan kerusakan ginjal, skor 2 (ringan): bila luas kerusakan ginjal $<25 \%$, skor 3 (sedang): bila kerusakan ginjal seluas $26-50 \%$, skor 3: bila kerusakan ginjal seluas 50\%.16

Data penelitian adalah skor perubahan histopatologi hepar, ginjal dan jumlah rata sel alfa dan sel beta pulau langerhans pankreas. Data dengan skala kategorik dianalisis dengan uji Kruskal-Wallis dilanjutkan dengan uji Man Whitney untuk mengetahui kelompok mana terdapat perbedaan bermakna. Data dengan skala numerik diuji normalitas dan homogenitasnya, bila normal dianalisis dengan One Way Anova untuk mengetahui ada tidaknya perbedaan rerata lebih dari dua kelompok. Bila ada perbedaan bermakna akan diuji LSD untuk mengetahui antara kelompok mana yang berbeda.

\section{HASIL}

Selama penelitian berlangsung terdapat 5 tikus yang drop out yaitu 1 tikus dalam kelompok K1, K2, K3, K4 dan K5. Jumlah akhir hewan coba dalam penelitian ini adalah 25 , yang terdiri dari 4 tikus pada kelompok K1,
4 tikus pada kelompok K2, 4 tikus pada kelompok K3, 4 tikus pada kelompok K4, 4 tikus pada kelompok 5 dan 5 tikus pada kelompok 6. Unit percobaan penelitian ini adalah kandang hewan coba, sehingga dalam satu kandang berisi 5 hewan coba, jadi terjadi kesalahan dalam menentukan unit penelitian. Unit penelitian yang benar adalah organ hepar, pankreas dan ren pada setiap ekor tikus dalam tiap kelompok penelitian. Pada penelitian ini, jumlah minimal hewan coba dalam tiap kelompok penelitian adalah 4 ekor. Kami melakukan analisis dengan menggunakan empat hewan coba setiap kelompok dengan mempertimbangkan kemungkinan kematian tikus dalam kelompok K1 sampai K5 bukan disebabkan oleh variabel independen penelitian yaitu infusa teh hitam dan etanol 20\%, tetapi karena variabel pengganggu yang belum ditetapkan sebelumnya, yaitu kesalahan dalam menentukan unit penelitian.

Berdasarkan hasil pengamatan preparat histopatologi hepar (gambar 1), menunjukkan kelompok K1 dan K2 morfologi hepar yang normal, tampak hepatosit terlihat normal, sinusoid intak dan erirosit di dalamnya; K3 tampak infiltrasi sel limfosit pada parenkim terutama pada daerah porta, degenerasi hidropik, degenerasi mikrovesikuler dan sel-sel nekrotik, didapatkan Mallory bodies; K4 tampak sedikit infiltrasi sel radang di daerah porta dan sebagian besar sel mengalami degenerasi hidropik; K5 tampak degenerasi hidropik lebih sedikit; K6 tampak hepatosit dan sinusoid yang normal. Gambaran histopatologis ini menunjukkan adanya efek perbaikan pada kelompok infusa teh hitam dibandingkan dengan kelompok kontrol positif. 

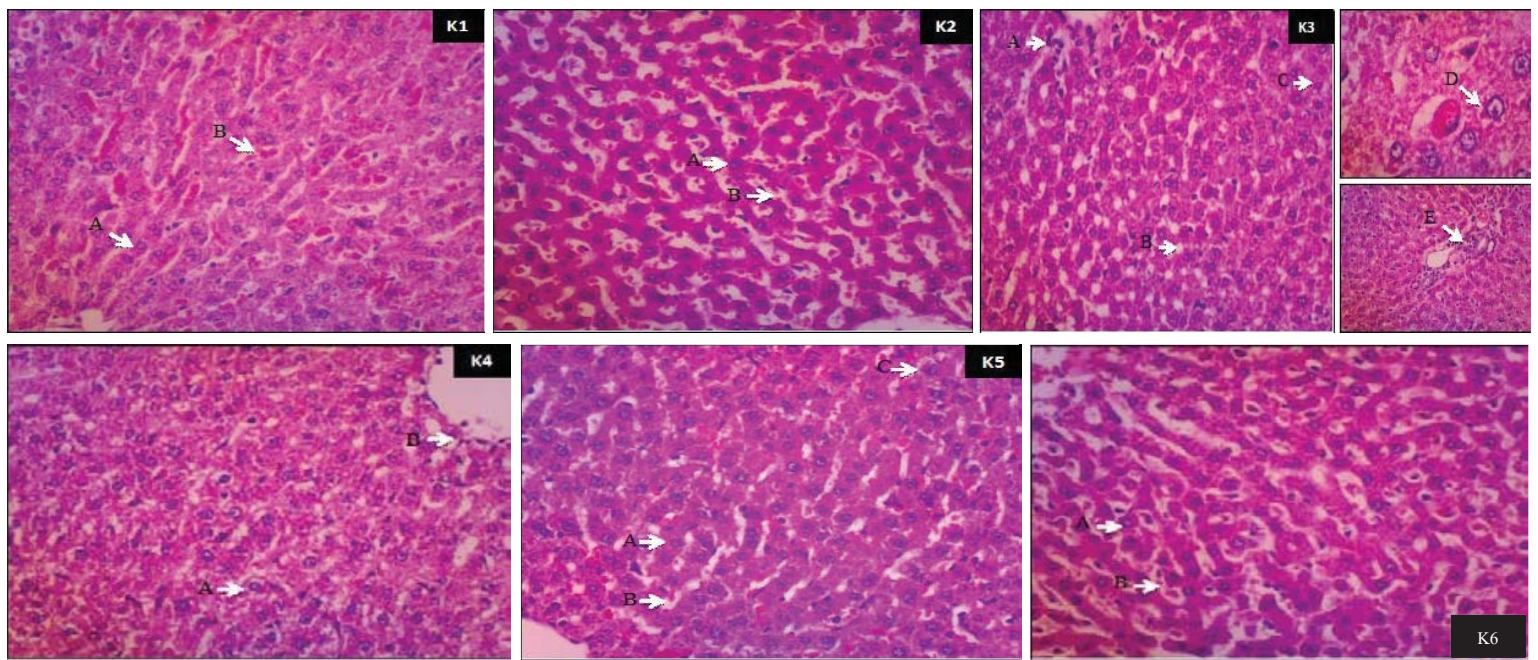

Gambar 1. Gambar histopatologi hepar dengan kamera optilab dengan perbesaran $100 \mathrm{X}$.

K1 dan K2: A. Hepatosit normal. B. Sinusoid dengan eritrosit. K3: A. Infiltrasi sel radang limfosit dan nekrosis B. Degenerasi lemak mikrovesikular. C. Degenerasi hidropik.

D. Perbesaran 400x Mallory Body . E. Infiltrasi sel radang di daerah porta. K4: A. Degenerasi Hidropik. B. Limfosit K5 dan K6: A. Hepatosit normal.

B. Sinusoid dan eritrosit. C. Degenerasi hidropik.

Penilaian derajat kerusakan hepar disimpulkan setelah mengamati preparat histopatologi hepar. Berikut ini adalah tabel hasil pengamatan histopatologi pada organ hepar.

Tabel 1. Derajat kerusakan hepar tiap kelompok

\begin{tabular}{cccccc}
\hline Kelompok & $\begin{array}{c}\text { Derajat } \\
\text { Kerusakan } \\
\mathbf{0}\end{array}$ & $\begin{array}{c}\text { Derajat } \\
\text { Kerusakan } \\
\mathbf{1}\end{array}$ & $\begin{array}{c}\text { Derajat } \\
\text { Kerusakan }\end{array}$ & $\begin{array}{c}\text { Derajat } \\
\text { Kerusakan }\end{array}$ & $\begin{array}{c}\text { Derajat } \\
\text { Kerusakan }\end{array}$ \\
\hline K1 & 0 & 4 & 0 & $\mathbf{3}$ & $\mathbf{4}$ \\
K2 & 2 & 2 & 0 & 0 & 0 \\
K3 & 0 & 0 & 0 & 0 & 0 \\
K4 & 0 & 1 & 1 & 2 & 0 \\
K5 & 0 & 3 & 1 & 0 & 0 \\
K6 & 1 & 3 & 0 & 0 & 0 \\
\hline
\end{tabular}

Hasil analisis menunjukkan adanya perbedaan bermakna $\mathrm{p}=0,004$ $(\mathrm{p}<0,05)$, dan dilanjutkan dengan uji Mann Whitney. Ada perbedaan bermakna antara K3 dengan $\mathrm{K} 1(\mathrm{p}=0,013), \quad \mathrm{K} 2 \quad(\mathrm{p}=0,018), \quad \mathrm{K} 5$ $(p=0,017)$ dan K6 $(0,017)$. Jadi ada perbaikan morfologi kerusakan hepar yang diinduksi etanol $20 \%$ pada peberian infusa teh hitam.
Sediaan histopatologi pankreas dengan perwarnaan Victoria blue pada kelompok K1 - K6, menunjukkan pulau Langerhans terdiri dari 2 kelompok sel, yaitu kelompok sel berwarna basofil di bagian tengah adalah sel-sel beta dan kelompok sel berwarna eosinofil di bagian tepi adalah sel-sel alfa (gambar 2). 

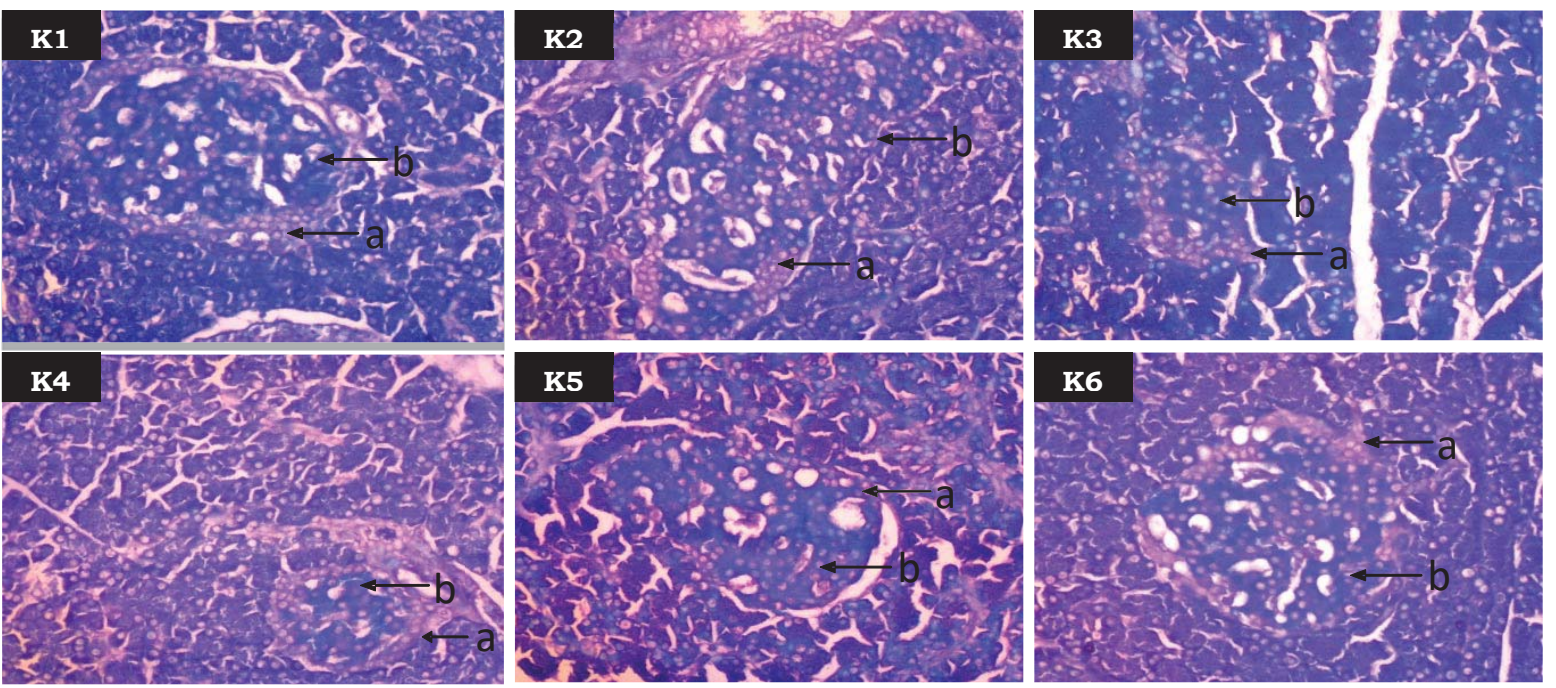

Gambar 2. Gambar diambil dengan kamera optilab dengan perbesaran 400X.

Gambaran histopatologi pulau langerhans tikus putih pada semua kelompok perlakuan $(\mathrm{K} 1, \mathrm{~K} 2, \mathrm{~K} 3, \mathrm{~K} 4, \mathrm{~K} 5$ dan K6) pada pewarnaan Victoria Blue. $\mathrm{a}=$ Sel alfa, $\mathrm{b}=$ sel beta.
Berdasarkan hasil pengamatan didapatkan rata-rata jumlah sel alfa dan sel beta pulau Langerhans pankreas (Tabel 2).

Tabel 2. Jumlah sel-sel alfa dan sel-sel beta pulau Langerhans pankreas

\begin{tabular}{ccc}
\hline Kelompok & Jumlah Rata-rata Sel Alfa & Jumlah Rata-rata Sel Beta \\
\hline K1 & $66,56 \pm 13,49$ & $109,12 \pm 13,28$ \\
K2 & $66,69 \pm 8,28$ & $109 \pm 14,48$ \\
K3 & $38,69 \pm 4,08$ & $44,62 \pm 3,96$ \\
K4 & $46,38 \pm 5,76$ & $66,31 \pm 8,39$ \\
K5 & $50,88 \pm 9,14$ & $77,12 \pm 15,76$ \\
K6 & $55,63 \pm 10,71$ & $91,93 \pm 13,55$ \\
\hline
\end{tabular}

Pada analisis didapatkan perbedaan bermakna jumlah rata-rata sel alfa dan sel beta pulau langerhans pankreas lebih dari dua kelompok eksperimental, yaitu $p=0,002$ untuk sel alfa dan 0,00 untuk sel beta $(\mathrm{p}<0,05)$. Analisis dilanjutkan dengan uji Post hoc LSD. Hasil analisis Post hoc menunjukkan, ada perbedaan bermakna jumlah sel alfa pankreas antara K3 dengan K1 $(\mathrm{p}=0,000), \mathrm{K} 2$ $(\mathrm{p}=0,000), \quad \mathrm{K} 6 \quad(\mathrm{p}=0,017) ; \quad$ ada perbedaan bermakna jumlah sel beta pankreas antara $\mathrm{K} 3$ dengan $\mathrm{K} 1$ $(p=0,000), \quad K 2 \quad(p=0,000)$ dan $K 4$ $(p=0,022), K 5(p=0,001), K 6(p=0,000)$. Jadi ada pertambahan jumlah sel alfa dan beta bila diberi infusa teh hitam.

Berdasarkan hasil pengamatan preparat ren (gambar 3) menunjukkan kelompok K1 dan K2 gambaran morfologi ren normal; K3 tampak sebagian besar lumen tubulus tertutup dan deskuamasi epitel pada sebagian tubulus, kongesti pembuluh darah, glomerulus atrofi, infiltrasi sel radang; K4 lumen tubulus yang tertutup lebih sedikit, glomerulus tampak atrofi; K5 dan K6 gambaran morfologi tubulus dan glomerulus mendekati kelompok K1 dan K2. 

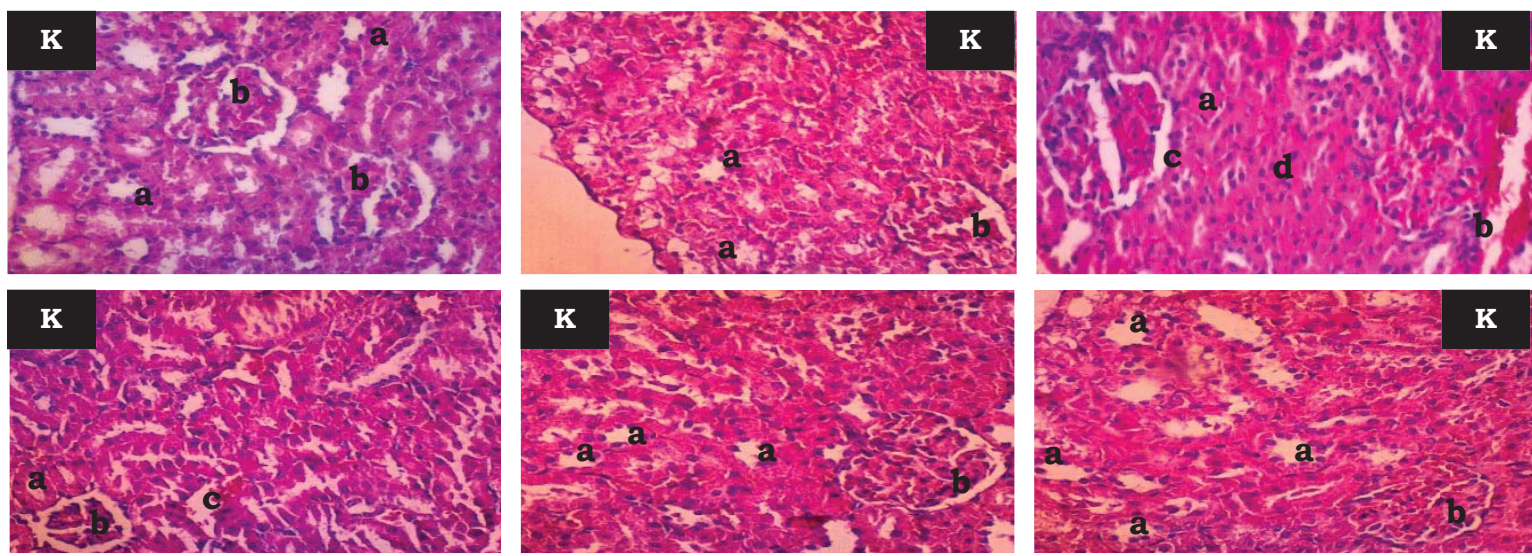

Gambar 3. Gambaran diambil dengan kamera optilab dengan perbesaran 400X.

Histopatologi ren kelompok k1: (a) Tubulus normal (b) Glomerulus normal K2: (a) Tubulus normal (b) Glomerulus normal K3: (a) Penutupan lumen tubulus (b) Kongesti pembuluh darah (c) Glomerulus (d) Dekstruksi epitel tubulus K4: (a) Tubulus (b)
Glomerulus (c) Kongesti pembuluh darah membaik K5: (a) Tubulus normal (b) Glomerulus K6: (a) Tubulus normal (b) Glomerulus.

Penilaian skor kerusakan ren berdasarkan pengamatan preparat ren ditunjukkan pada tabel 3.

Tabel 3. Skor kerusakan ren

\begin{tabular}{ccccc}
\hline Kelompok & Tikus 1 & Tikus 2 & Tikus 3 & Tikus 4 \\
\hline 1 & 4,25 & 4,91 & 4,64 & 5,95 \\
2 & 4,49 & 21,16 & 3,95 & 2,91 \\
3 & 52,69 & 52,36 & 54,26 & 58,13 \\
4 & 57,86 & 44,47 & 46,15 & 50,35 \\
5 & 46,22 & 28,71 & 22,65 & 24,92 \\
6 & 27,62 & 24,52 & 21,67 & 4,36 \\
\hline
\end{tabular}

Analisis menunjukkan adanya perbedaan bermakna rata-rata skor kerusakan ginjal $p=0,001 \quad(p<0,05)$, dan dilanjutkan dengan uji Mann Whitney. Ada perbedaan bermakna antara kelompok K3 dengan K1 $(p=0,011), K 2(p=0,011), K 5(p=0,013)$, K6 (p=0,013). Penelitian ini menunjukkan bahwa infusa teh hitam memperbaiki kerusakan ren yang diinduksi etano $20 \%$.

\section{PEMBAHASAN}

Mekanisme hepatoprotektif yang ditunjukkan pada penelitian ini terhadap cedera diinduksi alkohol melalui peningkatan antioksidan endogen. ${ }^{17}$ Aktivitas antioksidan teh hitam ditunjukkan dengan me- ningkatnya kadar glutathione peroxidase dan aktivitas katalase, meniadakan aktivitas peroksidasi dari ion-ion transisi metal melalui pembentukan chelate, menurunkan absorbsi zat besi di intestinal, memiliki aktivitas lipofilik sehingga mampu berpenetrasi menembus membran sel di mana mencegah aqueous lipid peroxidation yang diinisiasi zat besi $\left(\mathrm{Fe}^{2+}\right) \cdot{ }^{9}$ Theaflavins dapat menghambat akumulasi lipid intra hepatik. ${ }^{18}$ Mekanisme proteksi terhadap sel alfa dan sel beta pulau langerhans pankreas selain aktivitas antioksidan endogen juga disebabkan adanya regenerasi sel-sel pankreas. ${ }^{19,20}$ Mekanisme proteksi selsel epitel tubulus renal diperantarai 
oleh theaflavins dan epigallocatechin gallate komponen paling banyak dalam teh hitam melalui mekanisme anti stres oksidatif. ${ }^{21,22}$

Theaflavins (TF) dalam teh hitam memiliki aktivitas antioksidan yang hampir sama dengan catechins yang ada di teh hijau. TF adalah produk yang dibentuk setelah catechin dipolimerisasi, saat proses fermentasi menjadi teh hitam. ${ }^{23}$ Kadungan $\mathrm{TF}$ adalah (1-2\%) dalam daun teh hitam kering, atau 2 gram/ 100 gram teh hitam kering yang diekstrak dengan air kemudian dikeringkan. ${ }^{24}$ TF utama dalam the hitam adalah theaflavin (TF1), theaflavin-3-gallate $\left(\mathrm{TF}_{2} \mathrm{~A}\right)$, theaflavin-3'-gallate $\left(\mathrm{TF}_{2} \mathrm{~B}\right)$ dan theaflavin-3,3'-digallate $\left(\mathrm{TF}_{3}\right) . \quad$ Dari sekian theaflavins, terbanyak adalah $\mathrm{TF}_{3}(1,05 \%)$, kemudian $\mathrm{TF}_{2} \mathrm{~A}(0,34 \%)$, $\mathrm{TF}_{2} \mathrm{~B}(0,11 \%)$, dan $\mathrm{TF}_{1}(0,08 \%)^{23}$. Absorbsi theflavins (theaflavin 17,7\%, theaflavin-3-gallate 31,8\%, theaflavin3'-gallate $16,7 \%$, dan theaflavin-3,3'digallate $\quad 31,4 \%$ ). Konsentrasi theaflavinsetelah pemberian $700 \mathrm{mg}$ theaflavins setara dengan 30 cangkir the hitam, terdeteksi dalam plasma sukarelawan pria dan wanita sebesar 1,0 dan 0,5 $\mathrm{\mu g} / \mathrm{L}$ dan konsentrasi maksimum dalam urin sebesar 0,6 dan 4,2 $\mathrm{\mu g} / \mathrm{L}$ semuanya dalam dua jam. ${ }^{25}$ Penelitian bioaviabilitas TF3 pada mencit menunjukkan pemberian intragastik $500 \mathrm{mg} / \mathrm{kbBB}$, konsentrasi maksimal plasma $\left(\mathrm{C}_{\max }\right)$ dicapai setelah 6 jam sebesar 226,61 \pm $31 \mathrm{\mu g} / \mathrm{dL}$, diperlukan dosis yang jauh lebih besar untuk mencapai konsentrasi maksimal plasma 476,53 \pm 52 pada pemberian intravena $5 \mathrm{mg} /$ $\mathrm{kgBB}$. Hal ini menunjukkan absorbsi TF3 yang rendah. Systemic exposure pemberian TF3 intragastrik 20 kali lebih besar dibandingkan pemberian intravena.Bersihan plasma mencapai $50 \%$ setelah 4 jam dan setelah 12 jam tidak terdeteksi dalam semua organ setelah pemberian TF3 teradioaktif intravena. Maksimum ambilan TF3 teradioaktif intravena setelah 15 menit di ginjal, 30 menit di liver dan di lien, 1 jam di jantung dan paru.Pada pemberian TF3 peroral menunjukkan ambilan maksimum pada liver sebesar $0,07 \%$, di ginjal $0,02 \%$ dan di lien $0,015 \%$ setelah 6 jam dan masih terdeteksi setelah 24 jam kemudian. ${ }^{24}$ Farmakokinetik dari therubiginsbelum banyak diteliti karena sebagian besar senyawa belum terkarakterisasi. ${ }^{26}$

\section{KESIMPULAN}

Hasil penelitian ini infusa teh hitam memperbaiki gambaran histopatologi hepar, renal, dan meningkatkan jumlah sel-sel alfa dan sel-sel beta pankreas pada tikus putih (Sprague dawley) yang diberi etanol 20\% kronik. Penelitian ini merupakan penelitian awal yang memerlukan penelitian lanjutan berupa mekanisme antioksidatif dengan memeriksa parameter fungsi hepar dan renal, level antioksidan yang meningkat oleh pemberian infusa teh hitam, berbagai protein stres oksidatif dalam darah maupun ekspresinya dalam jaringan. Sedangkan untuk penelitian sel-sel pankreas perlu penyesuaian penggantian hewan coba yaitu memakai kelinci.

\section{DAFTAR PUSTAKA}

1. Hicks A. 2009. CurrentStatus and Future Development of Global Tea Production and Tea Products. AU Journal of Technology. 2 (4): 25164. 2009.

2. Dai J, Mumper RJ. Plant Phenolic: Extraction, Analisis and Their Antioxidant andAnticancer Properties. Molecules.15: 731352. 2010.

3. Yashin A, Yashin Y, Nemzer B. Determination of Antioxidant Activity in Tea Extracts, and Their Total Antioxidant Content. American Journal of Biomedical Sciences. 3(4): 322-35. 2011.

4. Peterson J, Dwyer J, Bhagwat S, Haytowitz D, Holden J, Eldridge 
AL, Beecher G, Aladesanmi J. Major flavonoids in dry tea. Journal of Food Composition Ana Analisis. 18: 487-501. 2005.

5. Mejia EG, Ramirez-Mares MV, Puangpraphant S. Bioactive componentsof tea: Cancer, inflammation and behavior. Brain, Behavoiour, and Immunity. 23: 721-31. 2009.

6. Lambert JD, Yang CS. Mechanism of Cancer Prevention by Tea Constituents. The Journal of Nutrition. 133 (10): 3262S-3267S. 2003.

7. Yashin AY, Boris VN, Combet E, Yashin YI. Determination of the Chemical Composition of Tea by Chromatographic Methods: A Review. Journal of Food Research. 4 (3): 56-88. 2015.

8. Hening SM, Niu $\mathrm{Y}$, Lee $\mathrm{NH}$, Thames GD, Minutti RR, Wang H, Go VLW, Heber D. Bioavailability and antioxidant activity of tea flavanols after consumption of green tea, black tea, or green tea extract supplement. American Journal of Clinical Nutrition. 80: 1558-64. 2004.

9. Luczaj W, Skrzydlewska E. Antioxidant properties of black tea in alcohol intoxication. Food and Chemical Toxicology. 42: 2045-51. 2004.

10. Wong-ekkabut J, Xu Z, Triampo W, Tang IM, Tieleman DP, Monticelli L. Effect of Lipid Peroxidation on the Properties of Lipid Bilayers: A Molecular Dynamics Study. Biophysical Journal. 93: 4225-36. 2007.

11. Shalbueva N, Mareninova $O G$, Gerloff A, Yuan J, Waldron RT, Pandol SJ, Gukovskaya AS. Effect of Oxidative Alcohol Metabolism on the Mitochondrial Permeability Transition Pore and Necrosis in a Mouse Model of Alcoholic Pancreatitis. Gastroenterology. 144: 437-46. 2013.
12. Adewale A, Ifudu O. Kidney injury, fluid, electrolite and acid-base abnormalities in alcoholics. Nigerian Medical Journal. 55 (2): 93-8. 2014.

13. Statistics Indonesia (Badan Pusat Statistik-BPS), National Population andFamilyPlanning Board (BKKBN), Kementerian Kesehatan (Kemenkes-MOH), and ICF International. IndonesiaDemographicand Health Survey 2012: AdolescentReproductive Health. Jakarta, Indonesia: BPS,BKKBN, Kemenkesand ICF International. 2013.

14. Suhadi. Preferensi Peminum Alkohol di Indonesia Menurut RISKESDAS. Buletin Penelitian Kesehatan. 39 (4): 154-64. 2007.

15. Baltaziak M, Skrzydlewska E, Sulik A, Famulski W, Koda M. Green tea as an antioxidant which protects againts alcohol induced injury in rats-a histopathological examination. Folia Morphologica. 63 (1): 123-26. 2003.

16. Mukti, Lestari. Pengaruh Pemberian Elstrak Etanol Kulit Buah Manggis (Garcinia Mangostana L) terhadap Perubahan makroskopis, Mikroskopis dan Tampilan Imunohistokimia Antioksidan Copper Zinc Superoxide Dismutase (Cu Zn SOD) pada Ginjal Mencit Jantan (Mus Musculus L) Strain DDW yang Dipapari oleh Monosodium Glutamate (MSG) Dibandingkan dengan Vitamin E. Tesis. Medan: Program Magister Ilmu Biomedik FK USU. 2013.

17. Ochanda SO, Rashid K, Wanyoko JK, Ngotho M, Faraj AK, Onyango CA, Wachira FN, Maranga DN. Fortification of alcohol benerage $(12 \% \quad v / v)$ with tea (Camellia sinensis) reduces harmfull effects of alcohol ingestion and metabolism in mouse model. BMJ 
Open Gastroenterol; 3(1); 000058. 2016.

18. Hanhineva K, Torronen R, BondiaPons I, Pekkinen J, Kolehmainen $\mathrm{M}$, Mykkanen $\mathrm{H}$, Poutanen $\mathrm{K}$. Impact of Dietary Polyphenols on Carbohydrate Metabolism. International Journal of Molecular Sciences. 11: 1365-1402. 2010.

19. Manikandan R, Sundaram R, Thiagarajan R, Sivakumar MR, Meiyalagan V, Arumugam M. Effect of Black Tea on Histological and Immunohistochemical Changes in Pancreatic Tissues of Normal and Streptozotocin-induced Diabetic Mice (Mus musculus). Microscopy Research and Technique. 72: 723-26. 2009.

20. Chung $\mathrm{CH}$, Levine F. Adult Pancreatic Alpha-Cells: A New Source of Cells for Beta-Cell Regeneration. The Review of Diabetic Study. 2010.

21. Jha A, Saha S, Verma R. Renoprotective Effect of Black Tea against Aflatoxin Induced Toxicity in Mice. Journal of Toxicology and Environmental Health Sciences. 6(1): 25-31. 2014.

22. Yamabe N, Yokozawa T, Oya T, Kim M. Therapeutic Potential of (-)
Epigallocatechin 3-O-Gallate on Renal Damage in Diabetic Nephropathy Model Rats. The Journal of Pharmacology and Experimental Therapeutics. 319: 228-36. 2006.

23. Leung LK, Su Y, Chen R, Zhang Z, Huang Y, Chen Z. Theaflavins in Blacki Tea and Catechins in Grees Tea Are Equally Effective Antioxidants. The Journal of Nutrition. 131 (9): 2248-51. 2001.

24. Maity S, Ukil a, Vedasiromoni JR, Das PK. Biodistribution and Pharmacokinetics of Theaflavin3,3'-Digallate, the Major Antioxidant of Black Tea, in Mice. International Journal of Pharmacology. 2 (2): 240-46. 2006.

25. Clifford MN, van der Hoof JJJ, Crozier A. Human studies on the absorption, distribution, metabolism, and excretion of tea polyphenols. The American Journal of Clinical Nutrition. 98(suppl): 1619S-30S. 2013.

26. Chow H-H S, Hakim IA. Pharmacokinetic and Chemoprevention Studies on Tea in Humans. Pharmacological Research. 64 (2): 105-112. 2011. 